\title{
Impact of Microfiltration on Particle Size Distribution, Volatile Compounds and Protein Quality of Pasteurized Milk during Shelf Life
}

\author{
Danfeng Wang ${ }^{1,2}$, Yuanrong. Zheng ${ }^{1}$, Zhenmin Liu' ${ }^{1}$, Guanlan $\mathrm{Hu}^{2}$, Yun. Deng ${ }^{2, *}$ \\ ${ }^{1}$ State Key Laboratory of Dairy Biotechnology, Dairy Research Institute, Bright Dairy \& Food Co., Ltd, Shanghai, China \\ ${ }^{2}$ Department of Food Science \& Technology, Shanghai Jiao Tong University, Shanghai, China \\ *Corresponding author: foodsjtu@gmail.com
}

Received November 26, 2014; Revised December 08, 2014; Accepted January 05, 2015

\begin{abstract}
The effects of microfiltration on particle size, volatiles, protein quality and proximate compositions in pasteurized milk were studied over 7 days at $4^{\circ} \mathrm{C}$. Changes in proximate compositions, $\mathrm{pH}$, particle size, amino acids and volatile compounds of microfiltered and pasteurized milk (MPM) and pasteurized milk (PM) were evaluated. The MPM had lower values of proteins and total solids, and possessed higher particle size compared with PM. The D10 and D50 in MPM were individually reduced by 8.3\% and 3.1\% from day 0 to 7 , and there were no differences for the D90. Sixty-one and 65 compounds were identified in the MPM and PM, respectively. The total contents of aliphatic hydrocarbons and alcohols in MPM decreased with storage length, while those of hydrocarbons, ketones, phenols, nitrogenous compounds and sulfide in PM increased with storage time. Other compounds clearly started to increase on day 4 and were reduced markedly by day 7. After 7 days, aliphatic hydrocarbons and alcohols decreased by $21.8 \%$ and $47.3 \%$ in MPM, while hydrocarbons, ketones and sulfide increased by $57 \%$, 5.4\% and $35.4 \%$ in PM, respectively. At the same storage time, the hydrocarbons, alcohols, aldehydes, acid and ketones were less in MPM than in PM. MPM had higher EAAI, BV and ePER values. These highlighted that microfiltration changes the compositions of volatiles and improves protein quality and stability during MPM shelf life.
\end{abstract}

Keywords: microfiltration, particle size distribution, flavour, protein quality, milk

Cite This Article: Danfeng Wang, Yuanrong. Zheng, Zhenmin Liu, Guanlan Hu, and Yun. Deng, "Impact of Microfiltration on Particle Size Distribution, Volatile Compounds and Protein Quality of Pasteurized Milk during Shelf Life.” Journal of Food and Nutrition Research, vol. 3, no. 1 (2015): 26-33. doi: 10.12691/jfnr-3-1-5.

\section{Introduction}

Shelf-life extension and safety improvement are the major concerns of the dairy industry. Microfiltration (MF) has emerged as a new process that enables the removal of bacteria, defatting of whey, separation of micellar casein and selective fractionation of globular milk fat $[1,2,3]$. The combinations of MF and different heat treatments in dairy processing are more effective in the destruction of microbes and the extension of shelf life [2,3,4,5].

From the perspective of sensorial quality characteristics of milk, rheological properties, odor, taste and stability are important for consumers [6,7]. In milk, fat droplets are surrounded by a membrane named the milk fat globule membrane, which mainly comprises proteins and phospholipids [8]. However, when milk is subjected to processing treatments, the fat globules are disrupted and their average diameter decreases dramatically [6,9]. Changes in particle size and particle size distribution (PSD) are important contributors to surface area, opacity, reactivity, rheological properties, aggregation or dissociation phenomena of dispersed systems $[8,10]$, which offer valuable indicators to predict the sensorial quality properties and stability of milk systems [6,11].

Milk represents a major source of dietary protein in humans because of its high nutritional quality. High milk protein quality is influenced by several factors, particularly amino acid composition and the bioavailability of the protein [12]. Heating could modify the structural, digestible and functional properties of proteins in the milk, depending on the applied thermal treatment and processing conditions [12,13,14]. An abundance of amino acids and peptides in milk contribute directly to its flavour; however, processing treatment could cause the formation of ammonia compounds, which result in unpleasant odors [12]. Lipid oxidation is also a major cause of the development of rancid flavour and odor, and a concomitant reduction in the acceptability and nutritional quality milk [15]. Milk flavour is delicate and subtle, and can be overshadowed by off-flavours, which reduce the sensory quality and economic value of dairy products [12]. Some distinctive volatiles have been used to identify freshness and deterioration, and to predict shelf life of milk [15]. Unfortunately, information about the changes of the particle size distribution, protein quality and volatiles of the microfiltered and pasteurized milk during shelf life is lacking. 
To date, studies have investigated the effect of microfiltration on microorganisms, proximate compositions and main quality attributes of milk $[1,2,3,4,16,17]$. However, no detailed information is available on the influence of this combined processing on the particle size, protein quality and volatile components of milk during shelf life. Therefore, the objectives of this study were to identify and quantify the major classes of volatile compounds in the microfiltered and pasteurized milk (MPM) using headspace solid-phase microextraction (HS-SPME) coupled with gas chromatography-mass spectroscopy (GC-MS), and to investigate the effect of the combination of MF with pasteurization on particle size distribution, amino acids and physiochemical quality during storage. Conventionally pasteurized milk (PM) was used as a comparator.

\section{Materials and Methods}

\subsection{Raw Milk and Milk Processing}

Fresh raw milk (3.4\% fat), collected from the Jinshan dairy farm (Shanghai, China), was centrifuged to at 4000 $\mathrm{g}$ for $30 \mathrm{~min}$ to remove the fat and leucocytes. After centrifugation, the skim milk (less than $0.1 \%$ fat) was microfiltrated through ceramic membranes (Tami, France) (nominal pore size: $1.4 \mu \mathrm{m}$; total membrane surface area: $13.3 \mathrm{~m}^{2}$; flow rate : $5 \mathrm{t} \cdot \mathrm{h}^{-1}$; inlet pressure: $2.5 \mathrm{bar}$ ) at $50^{\circ} \mathrm{C}$. The separated cream stream (35\% fat) of the fresh milk was heated at $120{ }^{\circ} \mathrm{C}$ for $4 \mathrm{~s}$ and then mixed with the permeate of microfiltration to the fat-adjusted whole milk (3.4\% fat). Then the mixture was homogenized (150/50 bar) at $65^{\circ} \mathrm{C}$ and pasteurized at $72^{\circ} \mathrm{C}$ for $15 \mathrm{~s}$, and cooled to $4^{\circ} \mathrm{C}$ and then filled to give a stable product for volatiles analysis. After processing, all containers of all milk were stored in the dark at $4^{\circ} \mathrm{C}$ for the duration of the study. Analysis and testing were conducted at 0,4 , and $7 \mathrm{~d}$

\subsection{Chemical Analysis}

Crude fat content was determined by ether extraction [18], the total nitrogen (N) by the Kjeldahl method [18], and total solids by forced air oven drying [18]. Protein was calculated using the factor $\mathrm{N} \times 6.25$.

\section{3. pH Analysis}

The $\mathrm{pH}$ of the milk samples was monitored at $20^{\circ} \mathrm{C}$ using a standard $\mathrm{pH}$ meter (Model S400-K, METTLER TOLEDO, Switzerland).

\subsection{Particle Size Distribution Determination}

The particle size distribution of the milk was estimated by laser light scattering using a Malvern Mastersizer 3000 (Malvern Instruments, Malvern, UK). The samples were diluted in distilled water until an appropriate obscuration was obtained in the measurement cell. The stirred mixture was then continuously recycled through the sample cell of the Malvern with a laser wavelength of $633 \mathrm{~nm}$. An optical model based on the Mie theory of light scattering by spherical particles was applied using the following conditions: real refractive index of 1.520; refractive index of fluid (water) of 1.330; and a pump speed of $21 \%$. The size distribution was characterized by the diameter below which 50 or $90 \%$ of the volume of particles were found (D50 and D90, respectively).

\subsection{Amino Acid Analysis}

Amino acid compositions of milk samples were analyzed using an amino acid analyzer (L-8900, Hitachi, Japan) according to GB/T 5009.124-2003 [19]. On the basis of the amino acid composition, amino acid score (AAS), essential amino acid index (EAAI), estimated protein efficiency ratio (ePER), and biological value (BV) were calculated according to the reported method for evaluating protein quality [20].

\subsection{Volatile Compound Analysis}

Volatiles were collected by solid-phase microextraction (SPME) as described by Zhang et al. [20] with some modification. Briefly, a sample of $10 \mathrm{~mL}, 2 \mu \mathrm{L}$ of $0.1 \mathrm{mg} \cdot \mathrm{mL}^{-1}$ 2,4,6-trimethylpyridine in methyl alcohol (internal standard solution) and $3.7 \mathrm{~g}$ of $\mathrm{NaCl}$ were placed in an annealed $20 \mathrm{~mL}$ brown glass vial. The SPME fiber used was $50 / 30 \mu \mathrm{m}$ DVB/CAR on PDMS (Supelco, Bellefonte, PA, USA). The mixture was incubated at $50^{\circ} \mathrm{C}$ for 20 min with $500 \mathrm{rpm}$ vibration and the SPME fiber was exposed to the headspace above the sample for 30 min at $50^{\circ} \mathrm{C}$ with $250 \mathrm{rpm}$ vibration.

The headspace of the volatile compounds was analyzed using a 7890A gas chromatograph coupled with a 5975C mass spectrometer (Agilent Technologies, Palo Alto, CA, USA). An HP-INNOWax column (30 m × $0.25 \mathrm{~mm}$ i.d., $0.25 \mu \mathrm{m} \mathrm{df}$, Agilent) was used with helium as carrier gas at $1 \mathrm{~mL} \cdot \mathrm{min}^{-1}$ in a splitless mode. The column temperature was held at $40^{\circ} \mathrm{C}$ for $5 \mathrm{~min}$, increased to $220^{\circ} \mathrm{C}$ at $5^{\circ} \mathrm{C} \cdot \mathrm{min}^{-1}$, then to $250^{\circ} \mathrm{C}$ at $20^{\circ} \mathrm{C} \cdot \mathrm{min}^{-1}$ and held for 7.5 minutes. MS conditions were as follows: source $230^{\circ} \mathrm{C}$; electron impact ionization was recorded with an ionization energy of $70 \mathrm{eV}$ and mass spectra were scanned from 20 to 350 amu to identify the compounds based on the Saturn spectra reported on NIST Library. Relative retention times of detected compounds were also determined by n-alkane standard solutions (ASTM D2887-01 Calibration Mix, Restek, Pennsylvania, USA).

\subsection{Data Analysis}

Statistical analysis of variance (ANOVA) was performed using SAS 8.0 statistical data analytical software (SAS Inst., Inc., Cary, NC, USA). Significant differences between means were determined by a least significant difference (LSD) test procedure at $P<0.05$. All measurements were performed in triplicate.

\section{Results and Discussion}

\subsection{Proximate Compositions and $\mathrm{pH}$}

The total protein, fat, solids contents and $\mathrm{pH}$ in PM and MPM are shown in Table 1. MPM had lower contents of proteins and total solids (TS) compared with PM (except for protein on day 7). However, the fat contents were not significantly different between PM and MPM. Thus, the reduction in the TS could be related to decreased protein contents. The result obtained for the loss of the total proteins on day 0 , approximately $2.4 \%$, is similar to that 
of the study carried out by Debon et al. [17] in the MF process, where the retention of proteins was about $96 \%$. The protein contents decreased slightly with storage time in PM, whereas the storage period did not influence $(P>$ 0.05) the proteins in MPM, or the TS in all milk samples (Table 1). Debon et al. [17] also stated that the protein or lipid contents were not affected by the storage period. The fat contents of all milk samples showed no statistically significant change $(P>0.05)$ during storage, indicating that there was no significant lipolysis during the storage period. These results agree with a previous report on sheep milk yogurts [21]. Protein content in PM slightly decreased during storage, which was explained by the fact that Serra et al. [22] analyzed hydrolization of casein and observed an increase in soluble nitrogen at the end of storage of yogurt, which resulted in a reduction in total protein content.

No significant differences in the $\mathrm{pH}$ were detected between PM and MPM (except for day 0) (Table 1). During storage, small decreases in $\mathrm{pH}$ were observed in all samples, which were accompanied by an increase in acidity. These results are similar to the change trends in the $\mathrm{pH}$ of homogenized milks observed after $24 \mathrm{~h}$ of storage at $4^{\circ} \mathrm{C}$ [23]. Debon et al. [17] noted a similar behavior in milk, where the $\mathrm{pH}$ decreased on days 1 and 21. According to previous studies, the reductions in $\mathrm{pH}$ in milk could be caused by post-acidification [24] or the partial inactivation of milk lipoprotein lipase, an enzyme associated with the casein micelle [23].

\subsection{Particle Size Distributions}

The average diameter of milk fat globules has a remarkable contribution to the technological suitability and nutritional value of milk. Particle size parameters for the different milks are shown in Table 2. A small peak at $0.2 \mu \mathrm{m}$ that corresponded to casein micelles and a main peak at $3.7 \mu \mathrm{m}$ that corresponded to fat globules characterized the particle size distribution curve of raw milk [6]. Generally speaking, raw milk has only one peak after homogenization, and the mode depends on the pressure of the homogenization. The particle size distribution curve of PM was characterized by one peak at $0.719 \mu \mathrm{m}$, whereas MPM showed the presence of a second small at small peak at higher diameters reflecting the formation of large casein particles or fat aggregates, whose peaks were at $0.719 \mu \mathrm{m}$ and $2.580 \mu \mathrm{m}$, respectively. These clusters can be formed through shared casein adsorbed onto the fat globules membrane or by coalescence of fat globules [8]. PM showed a reduction in fat globule size $(P<0.05)$ in all storage days studied compared with MPM, and the reduction in fat globule size achieved in the PMs for D90 values was highest, followed by D50 and D10. For PM, the fat globule size parameter (D1) on day 0 was higher than on day 4 and 7; however, no significant differences were detected for the D50 and D90 values over the 7-d shelf life. The values of D10 and D50 in MPM samples were greater on day 0 than day 4 and 7, and there were no significant difference for D90 values within 7 days, or for D10 and D50 values between day 4 and $7(P>0.05)$ (Table 2$)$. Fat globule size parameters of the two treatments after 7 days of cold storage showed no significant changes, indicating that the shelf life was stable and fat and protein were not further aggregated.

Generally, aggregation is an energy consuming process: the higher the temperature, the faster the protein and fat aggregate. Therefore, stronger heating would theoretically cause faster and greater particle size aggregation. However, severe heating intensities enhance the denaturation of whey protein. In addition, the presence of denatured whey proteins on the surface of casein micelles or fat globules would also sterically restrain the approach of other casein particles or fat globules and reduce the formation of dense clusters, as has been observed in gels of unheated milks [11].

Table 1. Protein, crude fat, total solids and pH of milk during shelf life

\begin{tabular}{|c|c|c|c|c|c|c|c|c|c|c|c|c|}
\hline & \multicolumn{3}{|c|}{ Protein (\%) } & \multicolumn{3}{|c|}{ Crude Fat (\%) } & \multicolumn{3}{|c|}{ Total solids (\%) } & \multicolumn{3}{|c|}{$\mathrm{pH}$} \\
\hline & od & $4 d$ & $7 d$ & $0 \mathrm{~d}$ & $4 d$ & $7 d$ & od & $4 d$ & $7 d$ & od & $4 d$ & $7 d$ \\
\hline PM & $\begin{array}{c}3.33 \pm 0 . \\
03^{\mathrm{Aa}}\end{array}$ & $\begin{array}{c}3.31 \pm 0.0 \\
4^{\mathrm{ABa}}\end{array}$ & $\begin{array}{c}3.26 \pm 0.0 \\
1^{\text {BCa }}\end{array}$ & $\begin{array}{c}3.41 \pm 0 . \\
01^{\mathrm{Aa}}\end{array}$ & $\begin{array}{c}3.39 \pm 0 . \\
03^{\mathrm{Aa}}\end{array}$ & $\begin{array}{c}3.42 \pm 0 . \\
02^{\mathrm{Aa}}\end{array}$ & $\begin{array}{c}12.46 \pm 0 . \\
04^{\mathrm{Aa}}\end{array}$ & $\begin{array}{c}12.50 \pm 0 . \\
05^{\text {Aa }}\end{array}$ & $\begin{array}{c}12.46 \pm 0 \\
03^{\mathrm{Aa}}\end{array}$ & $\begin{array}{c}6.63 \pm 0 . \\
01^{\mathrm{Aa}}\end{array}$ & $\begin{array}{c}6.54 \pm 0.0 \\
1^{\mathrm{Ca}}\end{array}$ & $\begin{array}{c}6.58 \pm 0 . \\
01^{\mathrm{Ba}}\end{array}$ \\
\hline $\begin{array}{c}\text { MP } \\
\text { M }\end{array}$ & $\begin{array}{c}3.25 \pm 0 . \\
05^{\mathrm{Ab}}\end{array}$ & $\begin{array}{c}3.22 \pm 0.0 \\
3^{\mathrm{Ab}}\end{array}$ & $\begin{array}{c}3.21 \pm 0.0 \\
3^{\mathrm{Aa}}\end{array}$ & $\begin{array}{c}3.42 \pm 0 . \\
03^{\mathrm{Aa}}\end{array}$ & $\begin{array}{c}3.42 \pm 0 . \\
04^{\mathrm{Aa}}\end{array}$ & $\begin{array}{c}3.32 \pm 0 . \\
05^{\text {Aa }}\end{array}$ & $\begin{array}{c}12.32 \pm 0 . \\
03^{\mathrm{Ab}}\end{array}$ & $\begin{array}{c}12.31 \pm 0 . \\
03^{\mathrm{Ab}}\end{array}$ & $\begin{array}{c}12.34 \pm 0 . \\
06^{\mathrm{Ab}}\end{array}$ & $\begin{array}{c}6.56 \pm 0 \\
02^{\mathrm{Ab}}\end{array}$ & $\begin{array}{c}6.53 \pm 0.0 \\
2^{\text {BCa }}\end{array}$ & $\begin{array}{c}6.55 \pm 0 . \\
044^{\mathrm{ABa}}\end{array}$ \\
\hline
\end{tabular}

PM: pasteurized milk; MPM: microfiltered and pasteurised milk; N: Total non-essential amino acids; E: Total essential amino acids; EAAI: essential amino acid index; BV: biological value; ePER: estimated protein efficiency ratio. Each value was expressed as mean \pm standard deviation ( $\mathrm{n}=3$ ). Means in the same row with the same letters were not significantly different $(P<0.05)$.

Table 2. Particle size distributions of milk during shelf life

\begin{tabular}{|c|c|c|c|c|c|c|c|c|c|}
\hline & \multicolumn{3}{|c|}{$\mathrm{D} 10(\mu \mathrm{m})$} & \multicolumn{3}{c|}{$\mathrm{D} 50(\mu \mathrm{m})$} & \multicolumn{2}{c|}{$\mathrm{D} 90(\mu \mathrm{m})$} \\
\hline & $0 \mathrm{~d}$ & $4 \mathrm{~d}$ & $7 \mathrm{~d}$ & $0 \mathrm{~d}$ & $4 \mathrm{~d}$ & $0 \mathrm{~d}$ & $4 \mathrm{~d}$ & $7 \mathrm{~d}$ \\
\hline \multirow{2}{*}{$\mathrm{PM}$} & $0.27 \pm$ & $0.25 \pm$ & $0.25 \pm$ & $0.62 \pm$ & $0.60 \pm$ & $0.61 \pm$ & $1.26 \pm$ & $1.27 \pm$ & $1.25 \pm$ \\
\cline { 2 - 9 } & $0.00^{\mathrm{Ab}}$ & $0.01^{\mathrm{BCb}}$ & $0.0^{\mathrm{ABb}}$ & $0.00^{\mathrm{Ab}}$ & $0.01^{\mathrm{Ab}}$ & $0.00^{\mathrm{Ab}}$ & $0.00^{\mathrm{Ab}}$ & $0.00^{\mathrm{Ab}}$ & $0.02^{\mathrm{Ab}}$ \\
\hline \multirow{2}{*}{$\mathrm{MPM}$} & $0.48 \pm$ & $0.44 \pm$ & $0.44 \pm$ & $1.94 \pm$ & $1.88 \pm$ & $1.90 \pm$ & $4.84 \pm$ & $4.71 \pm$ & $4.82 \pm$ \\
\cline { 2 - 9 } & $0.02^{\mathrm{Aa}}$ & $0.01^{\mathrm{Ba}}$ & $0.02^{\mathrm{Ba}}$ & $0.03^{\mathrm{Aa}}$ & $0.04^{\mathrm{Ba}}$ & $0.03^{\mathrm{Ba}}$ & $0.23^{\mathrm{Aa}}$ & $0.24^{\mathrm{Aa}}$ & $0.33^{\mathrm{Aa}}$ \\
\hline
\end{tabular}

PM: pasteurized milk; MPM: microfiltered and pasteurised milk.

Values were expressed as average \pm standard error $(\mathrm{SE})(\mathrm{n}=3)$. Means in same row with same online capital letters were not significantly different $(P<0.05)$. Means in same column with same online lowercase letters were not significantly different $(P<0.05)$.

\subsection{Protein Quality Indices}

The amino acid compositions of all samples are reported in Table 3 . Among the amino acids in the milks, glutamic acid was the most abundant, followed by proline, lysine/leucine, and aspartic acid /lysine, while methionine was present in the least amount. Rutherfurd and Moughan [25] reported a similar result for several milk proteins. The contents of glutamic acid, proline, aspartic acid, glycine, isoleucine and leucine initially reduced on day 4 and then slightly increased on day 7 in all samples, while those of serine, tyrosine, histidine and methionine initially 
increased on day 4 and then fell on day 7. No significant differences were found in the alanine contents (except for PM on day 4) $(P>0.05)$. The levels of lysine increased on day 7 compared with other storage times. The results showed no homogeneous trend for other amino acids. Furthermore, the levels of essential amino acids (E), nonessential amino acids $(\mathrm{N})$ or the ratio between $\mathrm{E}$ and $\mathrm{N}$ $(\mathrm{E} / \mathrm{N})$ did not show significant changes between PM and MPM for the same storage time. The contents of $\mathrm{N}$ were higher on day 4 than on day 0 or 7 , and there were no differences between day 0 and 7 . However, the values of $E$ and $\mathrm{E} / \mathrm{N}$ were lower on day 4 than on day 0 or 7 , and there was no difference between day 0 and 7 for all samples $(P>0.05)$ (Table 3$)$. Amino acids are usually susceptible to the processing conditions, which could decrease or maintain amino acid content depending on the material species, variety, age, amino acid type, process method and the part of the analyzed material $[13,25]$. Our experiments showed that microfiltration processing before pasteurization resulted in no visible changes in the concentration of $\mathrm{E}$ or $\mathrm{N}$ as well as the $\mathrm{E} / \mathrm{N}$ ration in the milk at the same storage time compared with PM.

Table 3. Amino acid compositions, essential amino acid index, estimated protein efficiency ratio and biological values of milk (\%)

\begin{tabular}{|c|c|c|c|c|c|c|}
\hline & \multicolumn{3}{|c|}{ PM } & \multicolumn{3}{|c|}{ MPM } \\
\hline Amino acids & $0 \mathrm{~d}$ & $4 \mathrm{~d}$ & $7 \mathrm{~d}$ & $0 \mathrm{~d}$ & $4 \mathrm{~d}$ & $7 \mathrm{~d}$ \\
\hline \multicolumn{7}{|c|}{ Non-essential amino acids } \\
\hline Aspartic acid & $7.91 \pm 0.46 b$ & $7.59 \pm 0.18 c$ & $8.10 \pm 0.02 \mathrm{ab}$ & $8.29 \pm 0.19 a$ & $7.99 \pm 0.05 b$ & $8.11 \pm 0.09 \mathrm{ab}$ \\
\hline Arginine & $3.34 \pm 0.01 \mathrm{ab}$ & $3.38 \pm 0.02 \mathrm{a}$ & $3.27 \pm 0.02 \mathrm{c}$ & $3.37 \pm 0.04 \mathrm{a}$ & $3.32 \pm 0.01 b$ & $3.29 \pm 0.04 b c$ \\
\hline Serine & $4.87 \pm 0.13 \mathrm{~b}$ & $5.12 \pm 0.12 \mathrm{a}$ & $4.77 \pm 0.14 b$ & $4.71 \pm 0.03 \mathrm{~b}$ & $5.08 \pm 0.05 a$ & $4.81 \pm 0.01 \mathrm{~b}$ \\
\hline Glutamic acid & $19.92 \pm 0.07 \mathrm{a}$ & $19.06 \pm 0.22 b$ & $20.14 \pm 0.18 \mathrm{a}$ & $18.80 \pm 0.47 b$ & $18.31 \pm 0.14 \mathrm{c}$ & $20.10 \pm 0.07 \mathrm{a}$ \\
\hline Proline & $10.01 \pm 0.07 \mathrm{bc}$ & $9.80 \pm 0.03 \mathrm{~d}$ & $9.86 \pm 0.26 \mathrm{~cd}$ & $10.24 \pm 0.09 \mathrm{a}$ & $9.94 \pm 0.04 \mathrm{bcd}$ & $10.04 \pm 0.16 b$ \\
\hline Glycine & $2.04 \pm 0.03 \mathrm{bc}$ & $1.94 \pm 0.03 \mathrm{~d}$ & $2.01 \pm 0.02 \mathrm{c}$ & $2.11 \pm 0.01 \mathrm{a}$ & $1.92 \pm 0.02 \mathrm{~d}$ & $2.07 \pm 0.00 \mathrm{ab}$ \\
\hline Alanine & $3.29 \pm 0.01 \mathrm{a}$ & $3.20 \pm 0.04 b$ & $3.35 \pm 0.01 \mathrm{a}$ & $3.34 \pm 0.03 a$ & $3.31 \pm 0.08 a$ & $3.32 \pm 0.04 a$ \\
\hline Tyrosine & $2.99 \pm 0.05 b c$ & $4.69 \pm 0.07 \mathrm{a}$ & $2.70 \pm 0.01 \mathrm{c}$ & $3.24 \pm 0.22 b$ & $4.61 \pm 0.38 \mathrm{a}$ & $2.68 \pm 0.00 \mathrm{c}$ \\
\hline Histidine & $3.31 \pm 0.02 \mathrm{~d}$ & $3.53 \pm 0.03 \mathrm{~b}$ & $3.27 \pm 0.01 \mathrm{~d}$ & $3.44 \pm 0.08 \mathrm{c}$ & $3.73 \pm 0.05 a$ & $3.25 \pm 0.01 \mathrm{~d}$ \\
\hline $\mathrm{N}$ & $57.68 \pm 0.21 b$ & $58.31 \pm 0.26 a$ & $57.49 \pm 0.34 b$ & $57.55 \pm 0.12 b$ & $58.24 \pm 0.39 a$ & $57.68 \pm 0.10 b$ \\
\hline \multicolumn{7}{|c|}{ Essential amino acids } \\
\hline Methionine & $2.38 \pm 0.03 c$ & $2.53 \pm 0.08 \mathrm{~b}$ & $2.41 \pm 0.04 \mathrm{c}$ & $2.49 \pm 0.03 \mathrm{~b}$ & $2.69 \pm 0.04 a$ & $2.41 \pm 0.04 \mathrm{c}$ \\
\hline Isoleucine & $5.57 \pm 0.24 \mathrm{~b}$ & $5.13 \pm 0.07 d$ & $5.78 \pm 0.05 a$ & $5.75 \pm 0.04 \mathrm{a}$ & $5.29 \pm 0.12 \mathrm{c}$ & $5.68 \pm 0.05 \mathrm{ab}$ \\
\hline Leucine & $9.94 \pm 0.02 \mathrm{bc}$ & $9.79 \pm 0.02 d$ & $10.01 \pm 0.12 b$ & $10.21 \pm 0.06 a$ & $10.15 \pm 0.09 a$ & $9.88 \pm 0.05 \mathrm{~cd}$ \\
\hline Phenylalanine & $5.46 \pm 0.09 \mathrm{~b}$ & $5.60 \pm 0.11 \mathrm{ab}$ & $4.84 \pm 0.09 c$ & $5.69 \pm 0.04 a$ & $5.58 \pm 0.15 a b$ & $4.97 \pm 0.03 c$ \\
\hline Lysine & $7.90 \pm 0.08 \mathrm{~b}$ & $8.05 \pm 0.14 \mathrm{~b}$ & $8.42 \pm 0.07 \mathrm{a}$ & $7.24 \pm 0.23 \mathrm{c}$ & $7.41 \pm 0.20 \mathrm{c}$ & $8.42 \pm 0.07 \mathrm{a}$ \\
\hline Threonine & $4.27 \pm 0.02 \mathrm{ab}$ & $4.26 \pm 0.05 \mathrm{ab}$ & $4.25 \pm 0.02 \mathrm{ab}$ & $4.26 \pm 0.04 \mathrm{ab}$ & $4.38 \pm 0.17 \mathrm{a}$ & $4.17 \pm 0.13 b$ \\
\hline Valine & $6.78 \pm 0.03 a$ & $6.32 \pm 0.08 \mathrm{~b}$ & $6.80 \pm 0.00 \mathrm{a}$ & $6.80 \pm 0.03 a$ & $6.27 \pm 0.11 \mathrm{~b}$ & $6.80 \pm 0.02 \mathrm{a}$ \\
\hline$E$ & $42.31 \pm 0.30 \mathrm{a}$ & $41.68 \pm 0.26 b$ & $42.51 \pm 0.34 a$ & $42.45 \pm 0.15 a$ & $42.39 \pm 0.08 b$ & $41.76 \pm 0.39 a$ \\
\hline $\mathrm{E} / \mathrm{N}$ & $73.38 \pm 0.65 a$ & $71.48 \pm 0.76 b$ & $73.96 \pm 1.02 \mathrm{a}$ & $73.76 \pm 0.38 \mathrm{a}$ & $71.72 \pm 1.14 \mathrm{~b}$ & $73.39 \pm 0.30 \mathrm{a}$ \\
\hline \multicolumn{7}{|l|}{ Indices } \\
\hline EAAI & $95.98 \pm 0.44 c$ & $98.00 \pm 0.77 b$ & $95.84 \pm 0.61 \mathrm{c}$ & $97.28 \pm 0.47 b$ & $99.35 \pm 0.15 a$ & $95.31 \pm 0.23 c$ \\
\hline BV & $92.92 \pm 0.48 c$ & $95.12 \pm 0.84 b$ & $92.77 \pm 0.67 \mathrm{c}$ & $94.34 \pm 0.51 b$ & $96.60 \pm 0.16 a$ & $92.18 \pm 0.25 c$ \\
\hline ePER & $4.67 \pm 0.00 \mathrm{~b}$ & $4.42 \pm 0.00 \mathrm{~d}$ & $4.73 \pm 0.05 a$ & $4.76 \pm 0.03 a$ & $4.59 \pm 0.03 \mathrm{c}$ & $4.67 \pm 0.02 b$ \\
\hline
\end{tabular}

PM: pasteurized milk; MPM: microfiltered and pasteurised milk; N: Total non-essential amino acids; E: Total essential amino acids; EAAI: essential amino acid index; BV: biological value; ePER: estimated protein efficiency ratio. Each value was expressed as mean \pm standard deviation (n=3). Means in the same row with the same letters were not significantly different $(P<0.05)$.

The EAAI and BV indexes demonstrated the same variation tendency during shelf life: the EAAI or BV values were higher in MPM on day 4 than in PM on day 4 and in MPM on day 0, they are lowest in other milks, moreover, they also showed no significant differences among MPM on day 7, PM on day 0 and 7. The ePER values of PM on day 7 and MPM on day 0 were the highest, followed by those of PM on day 0/MPM on day 7 , and MPM on day 4, the smallest ePER values were found in PM on day 4. The EAAI, BV, and ePER indexes of MPM were higher than those of PM at the same storage time (except for on day 7). High EAAI, BV, and ePER values showed high protein quality of the milk. Overall, the MF combined with pasteurization could retain or improve the protein quality in the milk compared to the pasteurization alone.

\subsection{Volatile Compounds Profiles}

Table 4 shows that 61 and 65 volatile compounds could be identified in MPM and PM, respectively, which were organized into the following chemical groups: aliphatic hydrocarbons, alcohols, aldehydes, ketones, acids, esters, aromatic hydrocarbons, phenols, nitrogenous and sulfo compounds. About 55 volatiles were detected in both MPM and PM. In particular, six compounds ( $\beta$-pinene, ocymene, tetrahydro-6-propyl-2H-pyran-2-one, propanoic acid butyl ester, butanoic acid butyl ester, and 1,2benzenedicarboxylic acid bis(2-methylpropyl) ester) were only characterized in MPM. The analysis of PM showed an additional detection of 2,2,4,6,6-pentamethyl-heptane, longifolene, benzene, ethanol, 1-octen-3-ol, Propanoic acid, n-hexadecanoic acid, acetoin, acetic acid 2ethylhexyl ester, 2-Ethylhexyl acrylate, compared with MPM.

The hydrocarbons are numerically the most representative class, which can be formed by lipid autoxidation processes, or by the decomposition of carotenoids [12]. They have a very limited influence on foodstuffs because they have a high perception threshold $[12,15,26]$. Storage led to a decrease in heptane, dodecane, tridecane, o-xylene and styrene, but increased or retained the levels of decane, 6-ethyl-2-methyl- octane, tetradecane, pentadecane, toluene and ethylbenzene in both milks. The 
levels of $\beta$-pinene (the smell of pine needles or resin) and o-cymene decreased or remained unchanged for MPM depending on storage time, while those of longifolenes increased over the storage period in PM. These terpenes originate from pasture plants and are then transferred to milk and milk products by animal grazing [27]. Styrene, which has a strong plastic odor, was found at the highest concentration $(5.65 \mathrm{ng} / \mathrm{mL})$ in $\mathrm{PM}$ on day 0 and at the lowest level $(1.53 \mathrm{ng} / \mathrm{mL})$ in MPM on day 7.

Acids or ketones, numerically the second class after the hydrocarbons, were present in all the analyzed samples. Acids are derived from lipolysis, proteolysis or the fermentation of lactose, which are responsible for the lipolyzed flavour in milk [12]. In milk, carboxylic acids are not only crucial aromas themselves, but also are important precursors of other compounds, including methyl ketones, alcohols, aldehydes and esters [12]. The concentrations of butanoic acid, hexanoic acid, n-decanoic acid, 9-decenoic acid and tetradecanoic acid increased from day 0 to 4 and decreased or slightly changed from day 4 to 7 for all samples. Compared with day 0, storage decreased the levels of acetic acid, octanoic acid and dodecanoic acid for MPM, but increased those of heptanoic acid and n-hexadecanoic acid for PM. methyl ketones are the principal flavour compounds in Blue cheese and are formed by enzymatic oxidation of FFA to $\beta$-keto acids and their consequent decarboxylation to methyl ketones, which contribute to the pungent aroma of such dairy products [27]. Approximately 11 ketones were identified in all samples. Compared with day 0, storage caused the loss in acetone, 2-pentanone, 2-nonanone and 2-undecanone compounds from MPM, and enhanced the levels of acetone, 2-heptanone and 2-nonanone in PM as well as those of 1-phenyl-2-butanone and tetrahydro-6pentyl-2H-pyran-2-one in both MPM and PM. No differences were found for tetrahydro-6-propyl-2H-pyran2-one between day 4 and 7 for MPM, and the level of acetone initially increased after 4 days and markedly declined after 7 days.

The next groups numerically were the esters and alcohols. Esters are formed through two enzymatic reactions: esterification and alcoholysis. Esterification is the formation of esters from alcohols and carboxylic acids, whereas alcoholysis is the production of esters from alcohols and acylglycerols, or from alcohols or acylcoenzyme A [27]. The important contributions of ester compounds to food aromas are undisputed: esters with low numbers of carbon atoms are highly volatile at ambient temperatures and the perception thresholds are ten times lower than their alcohol precursors [12]. For MPM, storage treatments had positive effects on ethyl acetate, butyl ester acetic acid, and butyl ester propanoic acid (except at day 4), whereas the levels of methyl ester butanoic acid, butyl ester butanoic acid and butyrolactone decreased. For PM, the levels of ethyl acetate and butyrolactone decreased, while those of methyl ester butanoic acid and 2-ethylhexyl ester acetic acid increased compared with day 0.The content of 1,2benzenedicarboxylic acid, bis(2-methylpropyl) ester was higher on day 0 than on other days, and there were no changes between day 4 and 7 for MPM. Alcohols are derived from many metabolic pathways, i.e., metabolism of lactose and AA, degradation of methyl ketones, and the secondary hydroperoxides of fatty acids, and are considered to be important volatile compounds that may impart an alcoholic, winey, sweet, fruity, and harsh note in dairy products. Unsaturated alcohols, such as 1-octen-3-ol, play an important role in product odor, even if present in very small amounts. During the storage period, the contents of all alcohols (except for 2-ethoxy-ethanol) in MPM as well as 2-ethoxy-ethanol and 2-(2ethoxyethoxy)-ethanol in PM decreased. For PM, the levels of 1-octen-3-ol and 2-ethyl-1-hexanol increased during storage, and those of ethanol and 1-butanol initially increased and then decreased over the storage period.

In addition, four aldehydes (hexanal, octanal, benzaldehyde and nonanal), four nitrogenous and sulfo compounds (dimethyl sulfoxide, benzonitrile, methoxyphenyl-oxime and dimethyl sulfone), and two phenols (phenol, 2,5-bis(1,1-dimethylethyl)-Phenol) were detected. Aldehydes are produced by the catabolism of fatty acids or amino acids via decarboxylation or deamination, which can make quite a marked contribution to the overall flavour of the product because of their low olfactory perception level [27]. Hexanal is a volatile compound produced by the oxidation of linoleic acid, which contributes to the smells of oxidate and cod-liver oil, as well as the typical smell of grass and plants, whilst nonanal can be traced to the degradation of the fatty acids of the n-9 series, and Benzaldehyde is generally responsible for the almond, fruit and hazelnut flavours [12]. The amount of hexanal and nonanal firstly increased and then decreased during the storage period. The amounts octanal and benzaldehyde decreased by varying degrees depending on the storage time. The phenols were more or less increased in all samples during the storage period. Bendall [28] suggested that phenol compounds impart woody, smoky and burnt aromas to milk and have been considered as the agents responsible for the smell of cow urine. The sulfur-containing volatile compounds are potent odor-active compounds, even at low concentrations; therefore, they can rapidly cause a strong odor in food.

As shown in Table 4, among the various groups, ketones were present at the highest concentration (42.8\%$51.5 \%$ ), followed by acids, aromatic hydrocarbons, esters, nitrogenous compounds and sulfo compounds; the levels of phenols were the lowest $(0.1 \%-0.7 \%)$ (except for MPM on day 4) in both the MPM and PM. Among all identified volatile components, the dominant components were acetone, octanoic acid, methoxy-phenyl-oxime, hexanoic acid and n-decanoic acid in the milk on day 0 and day 4 . The major components were acetone, octanoic acid, methoxy-phenyl-oxime, hexanoic acid and 2,5-bis(1,1dimethylethyl)-phenol on day 7.

Table 4. Comparative volatile compositions of milk during storage. Average of three brands (ng $\mathrm{mL}^{-1}$ )

\begin{tabular}{|c|c|c|c|c|c|c|c|c|}
\hline \multirow{2}{*}{$\begin{array}{c}\mathrm{RT} \\
(\mathrm{min})\end{array}$} & \multirow{2}{*}{ Identifcation Compounds } & \multirow{2}{*}{$\begin{array}{c}\text { CAS } \\
\text { number }\end{array}$} & \multicolumn{3}{|c|}{ MPM } & \multicolumn{3}{|c|}{$\mathrm{PM}$} \\
\hline & & & $0 \mathrm{~d}$ & $4 \mathrm{~d}$ & $7 \mathrm{~d}$ & $0 \mathrm{~d}$ & $4 \mathrm{~d}$ & $7 \mathrm{~d}$ \\
\hline \multicolumn{9}{|c|}{ Aliphatic Hydrocarbons } \\
\hline 1.91 & Heptane & $142-82-5$ & $2.39 \pm 0.39$ & 1.50 & $0.92 \pm 0.09$ & $2.44 \pm 0.43$ & 1.94 & $1.94 \pm 0.48$ \\
\hline 4.30 & Heptane, 2,2,4,6,6-pentamethyl- & $13475-$ & - & - & - & $1.96 \pm 0.22$ & 2.40 & $2.40 \pm 0.29$ \\
\hline
\end{tabular}




\begin{tabular}{|c|c|c|c|c|c|c|c|c|}
\hline 5.29 & Decane & $124-18-5$ & $0.67 \pm 0.12$ & 1.04 & $0.88 \pm 0.14$ & $0.99 \pm 0.15$ & 1.61 & $1.61 \pm 0.3$ \\
\hline 5.61 & Octane, 6-ethyl-2-methyl- & 62016- & $2.01 \pm 0.37$ & 3.72 & $3.34 \pm 0.73$ & $2.98 \pm 0.23$ & 3.30 & $3.30 \pm 0.41$ \\
\hline 8.09 & Undecane & 1120-21- & $1.91 \pm 0.26$ & 0.83 & $1.27 \pm 0.20$ & $1.01 \pm 0.26$ & 1.10 & $1.10 \pm 0.11$ \\
\hline 8.21 & $\beta$-Pinene & $127-91-3$ & $1.77 \pm 0.03$ & 0.83 & $0.91 \pm 0.01$ & - & - & - \\
\hline 11.52 & Dodecane & $112-40-3$ & $2.13 \pm 0.29$ & 1.44 & $1.34 \pm 0.30$ & $1.94 \pm 0.15$ & 1.33 & $1.33 \pm 0.05$ \\
\hline 14.70 & Tridecane & $629-50-5$ & $0.82 \pm 0.05$ & 0.61 & $0.47 \pm 0.05$ & $0.76 \pm 0.17$ & 0.67 & $0.67 \pm 0.12$ \\
\hline 17.57 & Tetradecane & $629-59-4$ & $1.64 \pm 0.45$ & 1.40 & $1.22 \pm 0.27$ & $1.17 \pm 0.16$ & 1.66 & $1.66 \pm 0.44$ \\
\hline 20.24 & Pentadecane & $629-62-9$ & $0.13 \pm 0.04$ & 0.22 & $0.18 \pm 0.06$ & $0.30 \pm 0.12$ & 0.96 & $0.96 \pm 0.01$ \\
\hline 21.87 & Longifolene & $475-20-7$ & - & - & - & $1.81 \pm 0.36$ & 4.01 & $4.01 \pm 0.46$ \\
\hline \multicolumn{9}{|c|}{ Aromatic Hydrocarbons } \\
\hline 4.02 & Benzene & $71-43-2$ & - & - & - & $1.62 \pm 0.41$ & 1.41 & $1.41 \pm 0.14$ \\
\hline 6.55 & Toluene & $108-88-3$ & $5.54 \pm 0.88$ & 10.54 & $7.06 \pm 0.87$ & $6.36 \pm 0.28$ & 15.73 & $15.73 \pm 3.69$ \\
\hline 9.14 & Ethylbenzene & $100-41-4$ & $2.98 \pm 0.17$ & 5.16 & $4.17 \pm 0.65$ & $3.41 \pm 0.40$ & 6.66 & $6.66 \pm 1.05$ \\
\hline 9.40 & p-Xylene & $106-42-3$ & $1.12 \pm 0.19$ & 1.48 & $0.84 \pm 0.12$ & $1.80 \pm 0.35$ & 2.41 & $2.41 \pm 0.77$ \\
\hline 9.62 & o-Xylene & $95-47-6$ & $4.20 \pm 0.36$ & 3.87 & $2.72 \pm 0.47$ & $2.79 \pm 0.44$ & 5.67 & $5.67 \pm 0.21$ \\
\hline 13.52 & Styrene & $100-42-5$ & $4.84 \pm 0.37$ & 2.82 & $1.53 \pm 0.26$ & $5.65 \pm 0.22$ & 4.41 & $4.41 \pm 1.01$ \\
\hline 13.83 & o-Cymene & $527-84-4$ & $2.10 \pm 0.32$ & 1.5 & $1.55 \pm 0.15$ & - & - & - \\
\hline 14.16 & Benzene, 1,2,3-trimethyl- & $526-73-8$ & $1.00 \pm 0.23$ & 0.78 & $0.53 \pm 0.09$ & $1.05 \pm 0.30$ & 2.18 & $2.18 \pm 0.53$ \\
\hline 18.58 & Benzene, 1,2,4,5-tetramethyl- & $95-93-2$ & $0.53 \pm 0.02$ & 0.36 & $0.39 \pm 0.11$ & $0.57 \pm 0.07$ & 0.69 & $0.69 \pm 0.14$ \\
\hline 26.09 & Naphthalene & $91-20-3$ & $1.17 \pm 0.20$ & 0.94 & $0.71 \pm 0.12$ & $1.45 \pm 0.28$ & 2.34 & $2.34 \pm 0.88$ \\
\hline \multicolumn{9}{|c|}{ Alcohols } \\
\hline 3.88 & Ethanol & $64-17-5$ & - & - & - & $2.27 \pm 0.38$ & 5.07 & $5.07 \pm 1.43$ \\
\hline 10.12 & 1-Butanol & 71-36-3 & $2.56 \pm 0.38$ & 2.04 & $0.72 \pm 0.10$ & $1.85 \pm 0.04$ & 2.46 & $2.46 \pm 0.48$ \\
\hline 12.47 & Ethanol, 2-ethoxy- & $110-80-5$ & $1.24 \pm 0.19$ & 1.65 & $1.25 \pm 0.36$ & $2.53 \pm 0.17$ & 1.90 & $1.90 \pm 0.55$ \\
\hline 19.08 & 1-Octen-3-ol & 3391-86- & - & - & - & $0.49 \pm 0.08$ & 0.61 & $0.61 \pm 0.06$ \\
\hline 20.08 & 1-Hexanol, 2-ethyl- & $104-76-7$ & $0.74 \pm 0.12$ & 0.73 & $0.67 \pm 0.09$ & $3.32 \pm 0.23$ & 4.39 & $4.39 \pm 0.41$ \\
\hline 21.77 & 1-Octanol & $111-87-5$ & $1.85 \pm 0.29$ & 1.08 & $0.87 \pm 0.03$ & $0.50 \pm 0.08$ & 0.52 & $0.52 \pm 0.08$ \\
\hline 23.26 & Ethanol, 2-(2-ethoxyethoxy)- & $111-90-0$ & $1.69 \pm 0.23$ & 0.98 & $0.75 \pm 0.03$ & $2.14 \pm 0.41$ & 1.38 & $1.38 \pm 0.22$ \\
\hline \multicolumn{9}{|c|}{ Aldehydes } \\
\hline 7.88 & Hexanal & $66-25-1$ & $1.77 \pm 0.22$ & 4.41 & $2.55 \pm 0.42$ & $10.53 \pm 1.65$ & 14.64 & $14.64 \pm 3.68$ \\
\hline 14.49 & Octanal & $124-13-0$ & $1.94 \pm 0.33$ & 0.88 & $0.43 \pm 0.13$ & $1.88 \pm 0.30$ & 1.06 & $1.06 \pm 0.27$ \\
\hline 17.50 & Nonanal & $124-19-6$ & $0.59 \pm 0.10$ & 0.91 & $0.50 \pm 0.08$ & $0.81 \pm 0.08$ & 1.25 & $1.25 \pm 0.16$ \\
\hline 20.98 & Benzaldehyde & $100-52-7$ & $3.31 \pm 0.65$ & 2.38 & $2.07 \pm 0.11$ & $3.02 \pm 0.42$ & 2.49 & $2.49 \pm 0.52$ \\
\hline \multicolumn{9}{|c|}{ Acids } \\
\hline 19.47 & Acetic acid & 64-19-7 & $0.93 \pm 0.23$ & 0.51 & $0.45 \pm 0.02$ & $0.83 \pm 0.06$ & 1.95 & $1.95 \pm 0.33$ \\
\hline 21.60 & Propanoic acid & 79-09-4 & - & - & - & $0.46 \pm 0.03$ & $1.3 \pm$ & $1.3 \pm 0.62$ \\
\hline 23.73 & Butanoic acid & $107-92-6$ & $9.30 \pm 1.11$ & 11.17 & $6.38 \pm 0.56$ & $15.88 \pm 2.02$ & 24.01 & $24.01 \pm 3.60$ \\
\hline 28.54 & Hexanoic acid & $142-62-1$ & $44.42 \pm$ & 47.67 & $37.19 \pm 1.76$ & $69.46 \pm 7.35$ & 82.27 & $82.27 \pm 8.22$ \\
\hline 30.75 & Heptanoic acid & 111-14-8 & $0.33 \pm 0.08$ & 0.64 & $0.34 \pm 0.07$ & $0.52 \pm 0.13$ & 0.96 & $0.96 \pm 0.13$ \\
\hline 32.83 & Octanoic acid & $124-07-2$ & $73.10 \pm$ & 66.94 & $45.43 \pm 3.85$ & $104.79 \pm$ & 101.0 & $101.05 \pm$ \\
\hline 34.84 & Nonanoic acid & $112-05-0$ & $0.71 \pm 0.02$ & 0.70 & $0.45 \pm 0.03$ & $1.29 \pm 0.25$ & 0.97 & $0.97 \pm 0.59$ \\
\hline 36.74 & n-Decanoic acid & $334-48-5$ & $30.39 \pm$ & 42.56 & $18.07 \pm 2.83$ & $56.11 \pm 4.02$ & 71.98 & $71.98 \pm 2.32$ \\
\hline 37.84 & 9-Decenoic acid & 14436- & $1.80 \pm 0.47$ & 2.22 & $0.76 \pm 0.10$ & $2.72 \pm 0.43$ & 4.18 & $4.18 \pm 0.45$ \\
\hline 40.32 & Dodecanoic acid & $143-07-7$ & $3.88 \pm 0.74$ & 1.02 & $1.86 \pm 0.41$ & $5.16 \pm 0.75$ & 9.28 & $9.28 \pm 1.06$ \\
\hline 42.93 & Tetradecanoic acid & $544-63-8$ & $1.32 \pm 0.38$ & 1.72 & $0.65 \pm 0.04$ & $1.4 \pm 0.20$ & 2.81 & $2.81 \pm 0.41$ \\
\hline 45.25 & n-Hexadecanoic acid & $57-10-3$ & - & - & - & $0.87 \pm 0.01$ & 3.28 & $3.28 \pm 0.87$ \\
\hline \multicolumn{9}{|c|}{ Ketones } \\
\hline 2.48 & Acetone & $67-64-1$ & $182.27 \pm$ & 174.8 & $152.17 \pm$ & $307.58 \pm$ & 318.5 & $318.51 \pm$ \\
\hline 3.34 & 2-Butanone & $78-93-3$ & $11.20 \pm$ & 32.55 & $15.24 \pm 1.17$ & $33.86 \pm 0.87$ & 67.43 & $67.43 \pm$ \\
\hline 4.79 & 2-Pentanone & $107-87-9$ & $5.21 \pm 0.99$ & 4.33 & $3.63 \pm 0.66$ & $4.00 \pm 0.59$ & 6.24 & $6.24 \pm 0.66$ \\
\hline 11.15 & 2-Heptanone & $110-43-0$ & $20.02 \pm$ & 22.19 & $17.85 \pm 0.19$ & $24.71 \pm 3.79$ & 29.08 & $29.08 \pm 1.33$ \\
\hline 14.37 & 2-Octanone & 111-13-7 & $0.26 \pm 0.05$ & 0.27 & $0.22 \pm 0.03$ & $0.74 \pm 0.14$ & 0.57 & $0.57 \pm 0.15$ \\
\hline 14.44 & Acetoin & 513-86-0 & - & - & - & $0.93 \pm 0.19$ & 1.02 & $1.02 \pm 0.11$ \\
\hline 17.36 & 2-Nonanone & $821-55-6$ & $7.44 \pm 0.88$ & 7.25 & $6.99 \pm 0.69$ & $8.47 \pm 0.21$ & 10.95 & $10.95 \pm 0.80$ \\
\hline 20.49 & 2,5-Hexanedione & $110-13-4$ & $0.45 \pm 0.05$ & 0.41 & $0.31 \pm 0.02$ & $0.55 \pm 0.13$ & 0.52 & $0.52 \pm 0.18$ \\
\hline 22.76 & 2-Undecanone & $112-12-9$ & $5.60 \pm 0.78$ & 3.55 & $3.80 \pm 0.10$ & $6.73 \pm 1.00$ & 6.32 & $6.32 \pm 1.58$ \\
\hline 27.51 & 1-Phenyl-2-butanone & 1007-32- & $2.01 \pm 0.51$ & 2.30 & $2.61 \pm 0.44$ & $0.91 \pm 0.22$ & 1.29 & $1.29 \pm 0.77$ \\
\hline 30.90 & 2H-Pyran-2-one, tetrahydro-6-propyl- & $698-76-0$ & $0.42 \pm 0.12$ & 0.30 & $0.30 \pm 0.05$ & - & - & - \\
\hline 35.23 & 2H-Pyran-2-one, tetrahydro-6-pentyl- & $705-86-2$ & $1.41 \pm 0.26$ & 1.67 & $1.73 \pm 0.26$ & $1.71 \pm 0.11$ & 2.39 & $2.39 \pm 0.24$ \\
\hline \multicolumn{9}{|c|}{ Esters } \\
\hline 3.17 & Ethyl Acetate & $141-78-6$ & $7.05 \pm 0.76$ & 16.60 & $17.11 \pm 2.27$ & $4.35 \pm 0.52$ & 4.03 & $4.03 \pm 0.71$ \\
\hline 5.05 & Butanoic acid, methyl ester & $623-42-7$ & $2.73 \pm 0.41$ & 1.33 & $2.49 \pm 0.50$ & $2.34 \pm 0.63$ & 2.75 & $2.75 \pm 0.14$ \\
\hline 7.64 & Acetic acid, butyl ester & $123-86-4$ & $1.41 \pm 0.23$ & 1.65 & $2.69 \pm 0.07$ & $1.90 \pm 0.32$ & 3.01 & $3.01 \pm 0.62$ \\
\hline 9.82 & Propanoic acid, butyl ester & $590-01-2$ & $1.78 \pm 0.25$ & 1.73 & $2.06 \pm 0.20$ & - & - & - \\
\hline 12.36 & Butanoic acid, butyl ester & $109-21-7$ & $1.26 \pm 0.24$ & 0.36 & $1.16 \pm 0.26$ & - & - & - \\
\hline
\end{tabular}




\begin{tabular}{|c|c|c|c|c|c|c|c|c|}
\hline 17.24 & Acetic acid, 2-ethylhexyl ester & $103-09-3$ & - & - & - & $0.81 \pm 0.13$ & 1.11 & $1.11 \pm 0.45$ \\
\hline 19.94 & 2-Ethylhexyl acrylate & $103-11-7$ & - & - & - & $1.67 \pm 0.17$ & 2.82 & $2.82 \pm 0.63$ \\
\hline 23.57 & Butyrolactone & $96-48-0$ & $6.92 \pm 0.17$ & 1.98 & $1.24 \pm 0.19$ & $10.38 \pm 1.29$ & 1.17 & $1.17 \pm 0.49$ \\
\hline 41.16 & 1,2-Benzenedicarboxylic acid, bis(2- & $84-69-5$ & $1.59 \pm 0.23$ & 1.35 & $1.35 \pm 0.24$ & - & - & - \\
\hline \multicolumn{7}{|c|}{ Phenols } \\
\hline 31.79 & Phenol & $108-95-2$ & $0.88 \pm 0.14$ & 9.34 & $2.04 \pm 0.48$ & $1.05 \pm 0.14$ & 7.46 & $7.46 \pm 2.71$ \\
\hline 37.41 & Phenol, 2,5-bis & $96-76-4$ & $1.20 \pm 0.28$ & 1.23 & $54.7 \pm 5.85$ & $1.12 \pm 0.22$ & 1.72 & $1.72 \pm 0.22$ \\
\hline \multicolumn{7}{|c|}{ Nitrogenous Compounds \& sulfide } \\
\hline 21.95 & $67-68-5$ & $0.74 \pm 0.11$ & 0.81 & $0.74 \pm 0.02$ & $0.73 \pm 0.13$ & - & - \\
\hline 23.01 & Dimethyl Sulfoxide & $100-47-0$ & $0.68 \pm 0.10$ & 0.40 & $0.39 \pm 0.10$ & $1.05 \pm 0.14$ & 0.69 & $0.69 \pm 0.20$ \\
\hline 26.68 & Benzonitrile & - & $67.51 \pm$ & 51.58 & $35.51 \pm 5.03$ & $71.47 \pm 8.85$ & 133.9 & $133.92 \pm$ \\
\hline 29.65 & Oxime--, methoxy-phenyl-_ & $67-71-0$ & $0.88 \pm 0.09$ & 1.57 & $1.43 \pm 0.29$ & $1.05 \pm 0.05$ & $2.6 \pm$ & $2.6 \pm 0.89$ \\
\hline
\end{tabular}

RT: Retention time (min); MPM: microfiltered and pasteurised milk; PM: pasteurized milk.

Values were expressed as average \pm standard error (SE) $(n=3)$.

The evolution of volatiles was different in MPM and $\mathrm{PM}$, and several qualitative and quantitative changes were observed during storage (Table 4). The total contents of aliphatic hydrocarbons and alcohols in MPM or those of esters in PM decreased after 7 days of storage. The total levels of hydrocarbons, ketones, phenols, nitrogenous and sulfide compounds in PM or those of esters, phenols in MPM increased with storage time. Other compounds, such as aromatic hydrocarbons, aldehydes, acids, ketones and phenols in MPM as well as alcohols, aldehydes and acids in the PM, clearly started to increase on day 4 but were reduced markedly on day 7 . At the same storage time, the total concentrations of hydrocarbons, alcohols, aldehydes and acid ketones were lower in MPM than in PM. However, esters, nitrogenous compounds and sulfo compounds showed the reverse trend. These differences between MPM and PM might reflect MF's ability to remove microbes and selectively fractionate the components in the milk, resulting in different reactions and compositions during processing and storage. Reports on the changing behavior of volatiles during storage did not show the same clear trend, or are contradictory, which may be influenced by milk source, compositions, processing and storage conditions [12,15,26,29].

\section{Conclusions}

The combination of $\mathrm{MF}$ and a subsequent pasteurization treatment $\left(72^{\circ} \mathrm{C}\right.$ for $\left.15 \mathrm{~s}\right)$ has proved to be an adequate tool for the extension of milk's shelf life. The changes in particle size, volatiles and quality of the proteins in MPM during storage were studied for the first time. Compared with PM, MF treatment enhanced protein quality, and decreased the levels of proteins and total solids. The essential amino acids (E), non-essential amino acids $(\mathrm{N})$, the $\mathrm{E} / \mathrm{N}$ ration, EAAI and $\mathrm{BV}$ indexes did not vary widely at the same storage time among all samples. MF also can cause varying degrees of alteration of the number, concentrations and groups in MPM, which results in the differences in flavour between MPM and MP during storage. The separation, identification and quantification of the changes in the key aroma compounds during storage of MPM will be addressed in the future.

\section{Abbreviations}

PM: pasteurized milk; MPM: microfiltered and pasteurised milk; N: Total non-essential amino acids; E: Total essential amino acids; EAAI: essential amino acid index; BV: biological value; ePER: estimated protein efficiency ratio.

\section{Acknowledgement}

This work was supported by the State Key Laboratory of Dairy Biotechnology, Bright Dairy \& Food Co. Ltd. (SKLDB2013-02) and the Shanghai Minhang District Commission of Science and Technology (2013MH088). Special thanks to SJTU-Instrumental Analysis Center for expert assistance with the GC-MS experiments.

\section{References}

[1] Schmidt, V. S.J, Kaufmann, V., Kulozik, U., Scherer, S. and Wenning, M., "Microbial biodiversity, quality and shelf life of microfiltered and pasteurized extended shelf life (ESL) milk from Germany, Austria and Switzerland”. Int. J. Food Microbiol. 154, 1-9, 2012.

[2] Caplan, Z. and Barbano, D., "Shelf life of pasteurized microfiltered milk containing 2\% fat”. J Dairy Sci. 96, 8035-8046, 2013

[3] Fernádez Garc, L. and Riera Rodr Guez, F. A., "Combination of microfiltration and heat treatment for ESL milk production: Impact on shelf life”. J. Food Eng. 128, 1-9, 2014.

[4] Elwell, M. and Barbano, D., "Use of microfiltration to improve fluid milk quality,” J. Dairy Sci. 89, E20-E30, 2006.

[5] Tomasula, P., Mukhopadhyay, S., Datta, N., Porto-Fett, A., Call, J., Luchansky, J., Renye, J. and Tunick, M., "Pilot-scale crossflowmicrofiltration and pasteurization to remove spores of Bacillus anthracis (Sterne) from milk”. J. Dairy Sci. 94, 4277-4291, 2011.

[6] Pereda, J., Ferragut, V., Quevedo, J., Guamis, B. and Trujillo, A., Effects of ultra-high pressure homogenization on microbial and physicochemical shelf life of milk”. J. Dairy Sci. 90, 1081-1093, 2007.

[7] Popov-Raljić, J. V., Lakić, N. S., Laličić-Petronijević, J. G., Barać, M. B. and Sikimić, V. M., "Color changes of UHT milk during storage”. Sensors, 8, 5961-5974, 2008.

[8] Fauquant, C., Briard-Bion, V., Leconte, N., Guichardant, M. and Michalski, M. C., "Membrane phospholipids and sterols in microfiltered milk fat globules”. Eur. J.Lipid Sci. Technol. 109, 1167-1173, 2007.

[9] Ye, A., Singh, H., Taylor, M. W. and Anema, S., "Interactions of whey proteins with milk fat globule membrane proteins during heat treatment of whole milk”. Le Lait, 84, 269-283, 2004.

[10] Beliciu, C. and Moraru, C., "Effect of solvent and temperature on the size distribution of casein micelles measured by dynamic light scattering”. J. Dairy Sci. 92, 1829-1839, 2009.

[11] Sodini, I., Remeuf, F., Haddad, S. and Corrieu, G., "The relative effect of milk base, starter, and process on yogurt texture: a review”. Crit. Rev. Food Sci. Nutr. 44, 113-137, 2004.

[12] Song, H. L., Food Flavour Chemistry. Beijing: Chemical Industry Press., 2008.

[13] Ham, J. S., Shin, J. H., Noh, Y. B., Jeong, S. G., Han, G. S., Chae, H. S., Yoo, Y. M., Ahn, J. N., Lee, W. K. and Jo, C., "Chemical and microbiological quality, capillary electrophoresis pattern, and 
rennet coagulation of UHT-treated and irradiated milk”. Food Sci. Biotechnol., 17, 58-65, 2008.

[14] Pedras, M. M., Tribst, A. A. and Cristianini, M., "Effects of highpressure homogenisation on physicochemical characteristics of partially skimmed milk,” Int. J. Food Sci. Technol. 49, 861-866, 2014.

[15] Valero, E., Villamiel, M., Miralles, B., Sanz, J. and MartınezCastro, I., "Changes in flavour and volatile components during storage of whole and skimmed UHT milk”. Food Chem. 72, 51-58, 2001.

[16] Lacroix, M., Bon, C., Bos, C., L Onil, J., Benamouzig, R., Luengo, C., Fauquant, J., Tom, D. and Gaudichon, C., "Ultra high temperature treatment, but not pasteurization, affects the postprandial kinetics of milk proteins in humans”. The J.Nutri. 138, 2342-2347, 2008.

[17] Debon, J., Prud Ncio, E. S., Petrus, J. C. C., Fritzen-Freire, C. B., M Ller, C. M., Amboni, R. D. D. M. and Vieira, C. R. W. "Storage stability of prebiotic fermented milk obtained from permeate resulting of the microfiltration process". LWT. 47, 96102, 2012

[18] AOAC. Association of Official Analytical Chemists. Official Methods of Analysis, 17th edn. Gaithersburg, MD: AOAC, 2000.

[19] GB 5413.27-2010. Determination of fatty acids in foods for infants and young children, milk and milk products. Standards Press of China: Beijing, China, 2010.

[20] Deng, Y., Wang, Y., Yue, J., Liu, Z., Zheng, Y., Qian, B., Zhong, Y. and Zhao, Y., "Thermal behavior, microstructure and protein quality of squid fillets dried by far-infrared assisted heat pump drying”. Food Control, 36, 102-110, 2014.
[21] Serafeimidou, A., Zlatanos, S., Kritikos, G. and Tourianis, A., "Change of fatty acid profile, including conjugated linoleic acid (CLA) content, during refrigerated storage of yogurt made of cow and sheep milk". J. Food Comp. Anal. 31, 24-30, 2013.

[22] Serra, M., Trujillo, A., Guamis, B. and Ferragut, V.,. "Proteolysis of yogurts made from ultra-high-pressure homogenized milk during cold storage”. J. Dairy Sci. 92, 71-78, 2009.

[23] Hayes, M. G. and Kelly, A. L., "High pressure homogenisation of raw whole bovine milk (a) effects on fat globule size and other properties”. J. Dairy Res. 70, 297-305, 2003.

[24] Kailasapathy, K., "Survival of free and encapsulated probiotic bacteria and their effect on the sensory properties of yoghurt". LWT. 39, 1221-1227, 2006.

[25] Rutherfurd, S. M. and Moughan, P., "The digestible amino acid composition of several milk proteins: application of a new bioassay”. J. Dairy Sci. 81, 909-917, 1998.

[26] Contarini, G., Povolo, M., Leardi, R. \& Toppino, P. M., "Influence of heat treatment on the volatile compounds of milk". $J$ Agri. Food Chem. 45, 3171-3177, 1997.

[27] Hayaloglu, A. A. and Karabulut, I., "SPME/GC-MS characterization and comparison of volatiles of eleven varieties of Turkish cheeses”. Int. J. Food Propert., 16, 1630-1653, 2013.

[28] Bendall, J. (2001). "Aroma compounds of fresh milk from New Zealand cows fed different diets”. J Agri. Food Chem., 49, 48254832, 2001

[29] Pan, D., Wu, Z., Peng, T., Zeng, X. and Li, H., "Volatile organic compounds profile during milk fermentation by Lactobacillus pentosus and correlations between volatiles flavour and carbohydrate metabolism”. J. Dairy Sci. 97, 624-631, 2014. 